\title{
Research on the Relationship between Reform and Development Based on the Implementation of China's Thirteen Five-Year Plans
}

\author{
Shuoxing Zheng, Zhili Ren \\ Shannxi Normal University, SNNU \\ Xi'an, China
}

\begin{abstract}
Since the reform and opening up in December 1978, China has achieved great economic development. The five-year plan has played a major role in guiding, planning, coordinating major national construction projects, as well as distributions of productive forces and important proportions of national economy. The reason why China achieves such great progress lies in reform and development in the implementation of every fiveyear plan. In order to figure out the relationship between reform and development, we can review industrialization and urbanization of every five-year plan. In conclusion, we should reform those which do not conform to production relations and objective laws, and we also want to develop China into a prosperous, strong, democratic, civilized and harmonious modern country. Reform is a driving force for development and the foundation for long-term stability. Development is a purpose of reform and is the most reliable guarantee. We should need both reform and development.
\end{abstract} Plans

Keywords-Reform; Development; Relationship; Five-year

\section{INTRODUCTION OF FIVE-YEAR PLAN}

The Five-Year Plan, which means the People's Republic of China national economic and social development Five-Year Plan outline, is an important part of the plan for national economy in China, belongs to a long-term plan and is filled with relationship between the reform and development. In fact, in consideration of implementation plan, process and results of The Five-Year Plan, we can know importance and necessity of reform and development. In this paper, we can find the relationship between reform and development through study of thirteen Five-Year Plan since founding of China. We should properly handle the relationship between reform and development. Specifically, we should firmly set up the reform and development of ideas. We need seek development in process of reform and adjust reform in process of development. Reform decides development, and development affects reform. They are mutually complementary and inseparable.

\section{THE BRIEF REVIEW OF THIRTEEN FIVE-YEAR PLANS}

From 1953 to 1957, our country implemented The First Five-Year Plan. At that time, basis of industrialization was very weak. The industrialization of the Soviet paths could help China establish a comprehensive industrialization in the short term. The reform of The First Five-Year Plan of contents were: First, the Chinese government focused on industrial construction, technical renovation on heavy industry, light industry and production of modern weapons, and strengthened the construction of national defense. Second, the Chinese government accelerated socialist transformation of agriculture, handicraft industry and capitalist industry and commerce. In particular, the Chinese government should reform agricultural cooperation in countryside and give priority to build publicprivate state capitalism. Based on the reform of industrialization and agriculture, handicraft industry and capitalist industry and commerce, before the end of The First Five-Year Plan, the socialist transformation in our country, basic construction, industry, agriculture and people's livelihood, and other fields has made great development. Socialist economy accounted for an absolute advantage in the national economy. At last, China completed total investment of 55 billion yuan, and industrial and agricultural output value reached 124.1 billion yuan. Therefore, reasonable and effective reform could bring developments. At the same time, it was the developments and achievements of The First FiveYear Plan that laid the foundation for the reform of The Second Five-Year Plan period.

With the successful implementation of The First Five-Year Plan and the developments of agriculture, handicraft industry and capitalist industry and commerce, China has made the great decision of implementation of The Second Five-Year Plan. The Second Five-Year Plan was officially implemented in 1958-1962. In early stage of the implementation of The Second Five-Year Plan, the reform of economic construction was carried out around the "great leap forward" and the "people's communalization" movement. The great leap forward, with steel as its core, led to emergence of national iron and steel industry and serious consequences of one-sided emphasis on speed of economic development and deformity of industrial development. Subsequently, the "people's communalization" promoted public agricultural areas, led to 
failure of individual incentive mechanisms and imbalance of industrial structures. Reform involved the national economy and the people's livelihood. In a good direction, the deepseated reform is sure to drive the development of industry, commerce, agriculture, transportation and major infrastructure. Reform should begin with good steps and roots, or it will have devastating consequences. In the late implementation of The Second Five-Year Plan, accompanied by dramatic ups and downs of industrial and agricultural, all indicators were not completed. Under this conditions, China take steps of the "adjustment, consolidate, enrich and improve" in a timely manner. In detail, the Chinese government adjust relations of proportion of national economic sectors, consolidate achievements in economic construction, enrich industrial products as raw materials for light industry and crafts production, improve product quality, enterprise management and labor productivity.

In the 1960s, as a result of China's peripheral deteriorating environment, the deteriorated sino-soviet relations, Vietnam war and the cultural revolution, therefore, The Third FiveYear Plan in $1966 \sim 1970$ made change from economic development to political movement. During this period, the Chinese government rarely touched reform of social and economic life, but bring capital, technology, manpower to national defense construction. Therefore, there is no outstanding performance on economic development. The national economy is close to stagnation. Development comes from reform, and it goes back to reform. The quality of development must be traced back to rigorous demonstration and scientific calculation.

The Fourth Five-Year Plan, which began in 1971 and ended in 1975, gradually adjusted strategy of war readiness and started to emphasize economic benefits. In The Fourth Five-Year Plan, our country put forward main tasks: accelerate process of agricultural mechanization, vigorously promote steel, military, industrial and transportation infrastructure and develop new technology. However, due to impact of the cultural revolution, economic reforms did not fully develop and developments of economics was greatly restricted.

The period from 1976 to 1980 was the implementation period of The Fifth Five-Year Plan. In early stage, China is in the last period of "cultural revolution". Then as the end of "cultural revolution", China gradually returned to normal social economic order. China's Economic development met a rare opportunity. The opening of the third plenary session of the eleventh central committee in 1978 and the beginning of reform and opening up brought hope to people.

The Sixth Five-Year Plan was implemented in China from 1981 to 1985 . In the 1980 s, peace and development replaced war and confrontation as a theme of world. China began to change its long-held view of war and revolution, focusing on domestic economic construction and institutional reform. Based on basic national conditions of primary stage of socialism, the convening of the third plenary session of the 11 th central committee represented whole party and whole nation strated to focus on economic construction. In field of agriculture, we will continue to expand scope of reform of household contract responsibility system. In field of opening- up, a number of special economic zones and coastal open cities were set up to reduce restrictions on foreign economic exchanges. At the same time, in field of science, education, culture and health, social development began to be incorporated into national development strategies. In field of economy and social development strategies, our country began to turn to improve economic benefit as a goal, paid attention to coordinated development, agriculture and heavy emphasis on economy, science and technology, education, culture and comprehensive development of society. In field of foreign economic relations, we began to turn to an open economy about international exchanges. In terms of relationship between quantity and quality, speed and efficiency, there was a lack of effective measures and effective supervision on improving economic efficiency, especially product quality. The measures to strengthen and improve macro-management failed to catch up in time while focusing on enhancing enterprise vitality.

The Seventh Five-Year Plan, which began in 1986 and ended in 1990, was an important period for China's reform. Peace and development, as a theme of world, continued to dominate development of world pattern. While international situation was turbulent, reform and liberalization became a major development trend of whole world during this period, and this trend also affected China's economic reform. At home, the reform of economic system began to shift from countryside to city, and comprehensive economic reform focused on the city began to move forward. In aspects of ownership reform, development of private economy and foreign capital economy was loosened. In aspects of enterprise reform, we should enhance autonomy of enterprises and start to separate government from government. Under this complicated political and economic situation, the completions of The Seventh Five-Year Plan was not ideal, with a basic completion rate of $71 \%$.

The Eighth Five-Year Plan began in 1991 and ended in 1995. During this period, the world tended to be peaceful. But local conflicts and wars were increasingly frequent. In 1992, Xiaoping Deng inspected Wuchang, Shenzhen, Zhuhai, Shanghai and other places and published a famous series of talks, known as "southern tour speeches". In the same year, the 14th national congress of the communist party of China announced that China regarded establishment of socialist market economic system as a goal of reform and opening up. During this period, the plan was put forward: improve economic efficiency and maintain sustained, stable and coordinated development of national economy. We will vigorously adjust industrial structure, promote rationalization of industrial structure, and promote rational division of labor and coordinated development of regional economy. By the end of the eighth Five-Year Plan period, breakthroughs were made in reform of economic system. The overall pattern of opening up to the outside world was basically formed, and rapid development of foreign trade and continued improvement of lives of both urban and rural people. It can be said that China has made a breakthrough in the economic field.

From 1996 to 2000, China implemented The Ninth FiveYear Plan. The implementation background of the plan were: in the world, economic restructuring of world accelerated, and 
emerging industries developed rapidly. At home, through macro-control, inflation was effectively controlled and national economy achieved a "soft landing". Therefore, based on this, China was committed to strengthening and improving macro-control, further liberalizing prices, and enhancing basic role of market in resource allocation. At the same time, the Chinese government reformed state-owned enterprises, rural areas, plans, investment, circulation, social security system, housing system reform and government institutions. By the end of The Ninth Five-Year Plan, China's per capita gross national product (GNP) quadrupled over 1980, and Chinese reached a well-off level. However, the reform of the property right system and government management system still lagged behind. The problems of "dual-track system" in the factor market remain prominent, and the income distribution system still needed to be improved.

The Tenth Five-Year Plan began in 2001 and ended in 2005. With China's accession to the World Trade Organization, economic globalization provided a rare opportunity to make China reform and open to outside deeply. But Asian financial crisis in 1997 caused a devastating disaster to our country economy. How to reform government's management system and further transform its functions into the world was a new problem to be solved. During this period, China established strategic adjustment of economic structure as a main task. The sustainable development of ecological construction, environmental protection, economy and society were paid more and more attention. The Chinese government focused on education, culture, health, sports, economic and social harmonious development, in order to better meet needs of developments of people and enjoy. From perspectives of how implementation it is, the tenth Five-Year Plan achieved a good overall performance. Most of proposed targets were achieved, and about two-thirds of planned indicators were successfully completed. During The Tenth Five-Year Plan, China's economy, the comprehensive national strength and people's life and opening to the outside world was again on a new step.

The Eleventh Five-Year Plan began in 2006 and ended in 2010. In the world, the trend of globalization continued to strengthen. How to integrate into the globalization wave became an inevitable question. At home, although social and economic environment was good, social contradictions were highlighted. During this period, our country accelerated upgrading of industrial structure and developments of service industry, promoted regional harmonious developments, constructed a resource saving and environment friendly society, and implemented a strategy of developing a country by relying on science and education. From completions of The Eleventh Five-Year Plan, economic growth target was completed ahead of schedule. The economic structure was continuously optimized, and public service and people's livelihood significantly were improved, and expected goal was basically achieved.

From 2011 to 2015, China implemented The Twelfth FiveYear Plan. At that time, the basic background were: Peace, development and cooperation remain trend of times. World multi-polarization and economic globalization developed in depth, and overall international environment was conducive to China's peaceful development. At the same time, impacts of the international financial crisis were far-reaching, and world economic growth slowed down and structure of global demand changed significantly. At home, industrialization, informatization, urbanization, marketization, internationalization developed fastly. Based on this, our country speeded up transformation of economic development patterns as a main line of economic system reform, efforted to adapt to changes in public demand and equal basic public services as a main line of social system reform, and continued to promote transformation of government as a main line of administrative system reform. In effect, China's economic output ranked the second place. Major progress was made in economic restructuring, agricultural stable growth, ratio of consumption and basic establishment. The Chinese government continued to expand coverage of public service system and reduced poverty population. People's living standards and quality further improved.

At present, China is in a period of The Thirteenth FiveYear Plan. Changes in our country shows three characteristics: rates of economic development, structural optimization and power transformation. In such a context, the Chinese government accelerates innovative development strategy, builts a new system development and advanced agricultural modernization and optimizes a modern industry system. The Chinese government constructs a modern infrastructure network, promotes balanced development among regions and improves level of people's livelihood security. However, to do a good job in economic reform, we need to optimize technology, intellectual property, patent system, and financial services. China also needs a wide range of communication and make an economic reform. This is a big problem.

\section{CONCLUSION}

Since implementation of The First Five-Year Plan in 1953, our country has experienced a lot of changes. We must see that under leadership of the CPC and the Chinese government, the living standards of Chinese are rising and overall national strength is increasing. Social undertakings have achieved gratifying achievements. At present, China is faced with the 13th five-year period, and the reform is in a tough stage and faces many challenges at all times. We need both reform and development. Reform is a driving force for development and foundation for long-term stability. Development is a purpose of reform and is the most reliable guarantee. Therefore, we must establish further for development and reform, seize moment and timely intensify reform, highlight China's characteristics. The reform and development should be based on innovation, especially the system innovation. Let us not forget our original intention, remember our mission, and move forward to realize the "two centenary goals" and to realize the Chinese dream of great rejuvenation of the Chinese nation!

\section{ACKNOWLEDGMENT}

On completion of this research paper, I would like to take this opportunity to express my heartfelt gratitude to all those who once assisted or encouraged me in writing this thesis. Without their great help or warm encouragement, this thesis could not have been completed in time. Naturally, their firm support and great expectations of me have been my greatest spiritual power for trying to do everything well, both in 
academics and in life, over the past decade. I will continue to study hard and strive for better results.

\section{REFERENCES}

[1] Donghua Chen, Oliver Zhen Li, Fu Xin. Five-year plans, China finance and their consequences [J]. China Journal of Accounting Research, 2017 10(03):189-226.

[2] HU An-Gang. The Five-Year Plan: A new tool for energy saving and emissions reduction in China [J]. Advances in Climate Change Research, 2016, 7(04):222-228.

[3] Luo Xiaolong, Xu Xiao, Li Min. Rural Transformation and Planning Tactics in the 13 (th) Five-Year Plan Period [J]. China City Planning Review, 2016, 25(01):31-40.

[4] Shen, Shen, Chen. Measurement of the new economy in China: big data approach [J]. China Economic Journal, 2016, 9(3).

[5] Ngai Pun, Ben Hok-bun Ku, Hairong Yan, Anita Koo. Social Economy in China and the World [M].Taylor and Francis: 2015-08-27.

[6] R. Nicole, "Title of paper with only first word capitalized," J. Name Stand. Abbrev., in press.

[7] Ron Berger, Chong Ju Choi, Ram Herstein. China' s Social Marke Economy: The Leverage of Economic Growth [J]. International Journal of Asian Business and Information Management (IJABIM), 2013, 4(1). 